UDC 330.322.011(470.6)

JEL E22, O18, R23

DOI 10.31375/2226-1915-2020-3-12-21

Lyudmila Shiryaeva

Ph.D. in Economics, professor, professor of the department

«Economy and Finance»

E-mail: 1.shyriaieva@gmail.com

ORCID ID: https://orcid.org/0000-0002-4706-2167

Yuliia Komarova

Student in Management

E-mail: ykomarova1999@gmail.com

Odessa National Maritime University, Odessa, Ukraine

\title{
ANALYSIS OF INVESTMENT ATTRACTIVENESS OF ODESSA REGION
}

Abstract. The Odessa region has great opportunities for investment development of the region. A considerable number of operating enterprises, the status of one of the largest tourist centers of the country and more than 1 million people provide a high internal demand for goods and services, as well as creates a good basis for further development of the production sector and transport industry. Active actions to attract local and foreign investments, as well as the policy of maximum transparency in relation to business on the part of local authorities, have a positive impact on the investment climate in the region, on the economic, human and social potential of the region. The article is devoted to the actual problem of increasing the investment attractiveness of the region. On the basis of the conducted researches the factors, which increase the investment attractiveness of the region, are singled out, and a number of measures, which help to increase the inflow of investments into the economy of Odessa region, are offered.

In recent years, the upgrade of the region's investment attractiveness rating has been due to the long-term growth of certain indicators of the region's social and economic development. The labor market is characterized by a high level of attraction of the population to the economic complex. According to the results of 2018, regional budget revenues increased by 15,6\% to 10,7 billion UAH. The level of fiscal capacity continues to exceed the average for the country and in 2018 amounted to 7,1 thousand UAH. - All this provides favorable conditions for attracting investments, in particular foreign ones.

The Odessa Regional Council is constantly taking measures to improve the investment climate, improve the quality of the region's management and provide administrative services.

For further attraction of investments into Odessa region it is necessary:

- facilitate preparation for implementation of pilot investment projects based on public and private partnership and introduce experience in implementation of pilot investment projects in different regions of the Odessa Oblast;

- improve the financial solvency of the region's population;

- remove barriers to foreign investment attraction;

- create and implement a mechanism for sharing experience in investment attraction with other regions of Ukraine and countries around the world;

- conduct master classes, trainings for the participants of investment projects in order to activate their activities; actively use the Internet resource and social networks to display information directly related to attracting investments; attract mass media representatives to the development of investment activities.

Keywords: investment attractiveness, rating estimation, marketing approach, Odessa region, investment activity.

\section{(C) Shiryaeva Lyudmila, Komarova Yuliia, 2020}


УДК 330.322.011(470.6)

JEL E22, O18, R23

DOI 10.31375/2226-1915-2020-3-12-21

Л.В. Ширяєва

д.е.н., професор кафедри «Економіка та фінанси»

E-mail: 1.shyriaieva@gmail.com

ORCID ID: https://orcid.org/0000-0002-4706-2167

Ю.В. Комарова

студент за спеціальністю «Менеджмент»

E-mail: ykomarova1999@gmail.com

Одеський начіональний морський університет,Одеса, Украӥна

\section{АНАЛІЗ \\ ІНВЕСТИЦІЙНОЇ ПРИВАБЛИВОСТІ ОДЕСЬКОГО РЕГІОНУ}

Анотація. 3 метою оцінки інвестиційної привабливості Одеського регіону в статті проаналізована динаміка об'єму капітальних вкладень, розглянуті основні чинники інвестиційної привабливості регіону, проведена оцінка рівня інвестиційної активності. Визначені пріоритетні напрями інвестиційної діяльності Одеської області.

Підвищення рейтингу інвестиційної привабливості регіону обумовлене тривалим зро-станням окремих показників сочіально-економічного розвитку області, діями місиевої влади з поліпшення інвестичійного клімату $i$ впровадженням політики «максимального сприяння» для бізнесу, модернізацією інфраструктури і трансnopmy.

Таким чином, тендениії розвитку соціально-економічних показників регіону пропориійні залученню інвестицій (якщо рівень розвитку даної території низький, то і рівень залучення інвестицій також знижується).

Ринок прачі характеризується високим рівнем залучення населення до господарського комплексу. За результатами 2018 року доходи бюджету області збільиилися на 15,6 10,7 млрд. грн.. Рівень бюджетної забезпеченості продовжує перевищувати середнє значення по краӥні 0, і в 2018 рочі склав 7,1 тис. грн. - усе ие роблять сприятливі умови для залучення інвестицій, зокрема, іноземних.

Залучення інвестииій в регіон є стратегічним напрямом сочіального і економічного розвитку регіону і Украӥни в иілому.

Ключові слова: інвестиційна привабливість, оцінка оцінки, маркетинговий підхід, Одеський регіон, інвестиційна діяльність.
УДК 330.322.011(470.6)

JEL E22, O18, R23

DOI 10.31375/2226-1915-2020-3-12-21

Л.В. Ширяева

д.э.н., профессор, профессор кафедры «Экономика и финансы»

E-mail: 1.shyriaieva@gmail.com

ORCID ID: https://orcid.org/0000-0002-4706-2167

Ю.В. Комарова

студент по специальности «Менеджмент» E-mail: ykomarova1999@gmail.com Одесский начиональный морской университет, Одесса, Украина

\section{АНАЛИЗ ИНВЕСТИЦИОННОЙ ПРИВЛЕКАТЕЛЬНОСТИ ОДЕССКОГО РЕГИОНА}

Аннотация. С иелью оценки инвестиичионной привлекательности Одесского региона в статье проанализирована динамика объёма капитальных вложений, рассмотрень основные факторы инвестиционной привлекательности региона, проведена оценка уровня инвестиционной активности. Определены приоритетные направления инвестиционной деятельности Одесской области. Повымение рейтинга инвестиционной привлекательности региона обусловлено длительным ростом отдельных показателей сочиально-экономического развития области, действиями местных властей по улучшению инвестиционного климата и внедрением политики «максимального благоприятствования» для бизнеса, модернизацией инфраструкmуры и транспорта.

Таким образом, тенденщии развития социально-экономических показателей региона пропорциональны привлечению инвестиций (если уровень развития рассматриваемой территории низкий, то и уровень привлечения инвестиций также снижается).

Рынок труда характеризуется высоким уровнем привлечения населения к хозяйственному комплексу. По результатам 2018 года доходь бюджета области увеличились на 15,6 \% до 10,7 млрд. грн. Уровень бюджетной обеспеченности продолжает превышать среднее значение по стране 0, и в 2018 году составил 7,1 тыс. грн. - все это оказывает благоприятные условия для привлечения инвестиций, в частности, иностранньх.

Привлечение инвестиций в регион является стратегическим направлением сочиального и экономического развития региона и Украинь в целом.

Ключевые слова: инвестииионная привлекательность, оценка оценки, маркетинговый подход, Одесский регион, инвестиционная деятельность. 
Problem statement. Attraction of investments into the region is a strategic direction of social and economic development of the region and Ukraine in general. Attraction of investments and cooperation with foreign investors is one of the main aspects that determine the development of the country as a whole and promote introduction of innovative technologies, improve the development of regional economy, increase local and state budgets, employment of the population and, as a result, improve their living standards. Today, foreign investment is the resource that can best contribute to the development of Ukrainian business enterprises and accumulation of capital in any form in the near future. From the point of view of development of interregional relations, the Odessa region, taking into account its geographical position, is an attractive object for investment activity on the part of representatives of foreign states, search of new forms of cooperation on the level of «state - region» and «region region».

Analysis of recent research and publications. Questions of attraction of the foreign capital to Ukraine have found the reflection in works of such known foreign scientists, as R. Solou, P. Romera, J. Bidzer, G. Gorg, V. Baumol, J. Bain, R. Brejl, O. Williamson, in works of the Ukrainian scientists: V. Bazilevicha, I. Blanka, A. Golikov, O. Kuzmin, O. Paskhaver and others. In connection with the need to attract financial resources and their limited availability, no less relevant today, there is another problem associated with the assessment and improvement of investment attractiveness of regions, as investment attractiveness acts as a characte- ristic, allows the investor to form an idea of the state of the object of investment, the reliability of future investment, the expected results of their use. In the years of reforming the Ukrainian economy these issues have already been considered in the works of I.A. Blank, M.V. Stirsky, V.M. Khobta, M.V. Lesnikova, A.V. Meshkov, M.V. Idrisov and other scientists. They offer different methods for solving this problem, from enterprise to state. However, for most the proposed approaches are characterized by a calculationonly orientation financial indicators, which leaves some issues unresolved. At the same time, new economic challenges, crisis phenomena and new principles of business organization make enterprises change and improve current tools for investment attractiveness management.

The concept of investment attractiveness is enough multi-faceted, so it's not fully defined and requires further research, as well as detailed consideration of factors, directly affect the level of investment attractiveness of Ukrainian regions.

Problem formulation. The aim of the article is to study the trend and prospects of investment activity in Ukraine by the example of the Odessa region. The analysis of the current state and improvement of ways of attraction of investments as directions of social and economic development of Odessa region, estimation of a role and a place of investments in regional development is conducted. The paper also considers the issues of territorial investment marketing based on the results of comprehensive monitoring of the investment climate of the region. 
The main results of the research. The Odessa region has great opportunities: rather rich natural resources, favorable climate conditions, wide opportunities for development of sea and river cruises, qualified labor - all these provide favorable conditions for attracting investments, in particular, foreign ones [1].

The region has: a developed logistics complex, a significant number of various educational institutions, developed service, municipal and social infrastructure. A considerable number of operating enterprises, the status of one of the largest tourist centers of the country and more than 1 million people provide a high internal demand for goods and services, and also creates a good basis for further development of the production sector and transport industry. Active actions to attract local and foreign investments, as well as the policy of maximum transparency towards business on the part of local authorities, have a positive impact on the investment climate in the region, on economic, human resources and social potential of the Oblast [2].

In recent years, the region has upgraded its investment attractiveness rating to iNSAA-(high investment attractiveness). Such rating levels reflect the region's significant investment attractiveness and high ability to pay off its obligations. For analytical research, statistical data was used, including: social and economic development indicators, treasury reports, program materials, as well as information from open sources.

The upgrade of the investment attractiveness rating is conditioned by the long-term growth of certain indica- tors of the region's social and economic development, actions of the local authorities to improve the investment climate and introduction of the «maximum-favorability» policy for business, modernization of infrastructure and transport.

Thus, trends in the development of socioeconomic indicators of a region are proportional to the attraction of investments (if the level of development of the territory in question is low, then the level of investment attraction also decreases). Let us consider the main development indicators of the Odessa Oblast:

1. Structure of the Oblast's economic complex and dynamics of key indicators. The Odessa Oblast's economy is diversified, which reduces the impact of adverse commercial factors in certain industries on its development and ensures stable revenues to the Oblast's budget. In 2018, there was a further growth of the key indicators of socio-economic development: the volume of sold industrial products increased by $25,6 \%$ to 3,3 billion UAH, construction works performed - by $50 \%$ to 12,1 billion UAH, retail turnover - by $6,4 \%$ to 36,7 billion $\mathrm{UAH}$, foreign trade turnover - by $13 \%$ to 1,2 billion USD. Foreign trade turnover - by $13 \%$ up to 1,2 billion USD. Most indicators in per capita terms continue to correspond to or exceed the national average.

2. The analysis of labor resources and labor market of the region under consideration is presented in Table 2. It can be concluded that the labor market is characterized by a high level of attraction of population to the economic complex - in large, medium and small businesses are involved (estimated) almost half of the region's population. 
During the first half of 2019 there was an increase in the number of vacancies, which were reported to the Odessa City Employment Service by employers, as well as information about employed persons and almost the same number of registered unemployed. In the presented period the volume of wage arrears decre-ased by $27,9 \%$ (up to 31,9 million UAH).

Table1

\section{Regional socio-economic development indicators}

\begin{tabular}{|l|c|c|c|c|}
\hline \multicolumn{2}{|c|}{ Indicators } & 2018 & 2019 & Growth rate \\
\hline $\begin{array}{l}\text { Volume of industrial } \\
\text { products sold }\end{array}$ & $\begin{array}{c}\text { UAH } \\
\text { million }\end{array}$ & 13188,0 & 16563,3 & $125,6 \%$ \\
\hline $\begin{array}{l}\text { Capital investment for } \\
\text { construction }\end{array}$ & $\begin{array}{c}\text { UAH } \\
\text { million }\end{array}$ & 4633,3 & 4583,8 & $98,9 \%$ \\
\hline Retail trade turnover & UAH million & 16284,6 & 19888,9 & $122,1 \%$ \\
\hline Foreign trade turnover & UAH million & 878,6 & 992,7 & $113,0 \%$ \\
\hline
\end{tabular}

Source: compiled by the authors on the material [3]

Regional demography and labor market indicators

Table 2

\begin{tabular}{|l|c|c|c|c|}
\hline \multicolumn{2}{|c|}{ Indicators } & 2018 & 2019 & Growth rate \\
\hline Population size & thousand persons & 1013,2 & 1014,1 & $100,1 \%$ \\
\hline $\begin{array}{l}\text { Average number of full-time } \\
\text { employees }\end{array}$ & thousand persons & 247,6 & 250,7 & $101,3 \%$ \\
\hline Registered as unemployed & thousand persons & 1,9 & 1,9 & $100 \%$ \\
\hline Businesses that are economically active & 6,7 & 6,6 & - \\
\hline Bankrupt & UAH million & 44,2 & 31,6 & - \\
\hline Wage arrears & & $72,2 \%$ \\
\hline
\end{tabular}

Source: compiled by the authors on the material [3]

3. Efficiency of financial policy and budget indicators.

According to the results of 2018 , the revenues of the region's budget increased by $15,6 \%$ to 10,7 billion UAH, which was due to an increase in revenues from own sources by $17,3 \%$ to 7,2 billion UAH, transfers from the budgets of higher levels - by $11,2 \%$ to 3,5 billion UAH. The share of tax revenues in the structure of the regional budget was $56,8 \%$; such revenues are diversified by payers and industries, which provide relative stability and predictability to the budget. The level of fiscal capacity continues to exceed the average for the country and in 2018 amounted to 7,1 thousand UAH. The budget of the 
region remains a donor budget, transferring to the state budget the reverse subsidy - 232,3 million UAH in 2018 against 156,6 million UAH in 2017. Due to the increase in current expenditures, expenses for servicing loans while main- taining a high level of financing capital expenditures, the city budget was executed with a deficit of 595 million UAH, which was covered by balances and borrowed capital.

Table 3

Budgetary security of the region

\begin{tabular}{|l|c|c|c|c|}
\hline \multicolumn{2}{|c|}{ Indicators } & 2018 & 2019 & $\begin{array}{c}\text { Growth } \\
\text { rate }\end{array}$ \\
\hline Budget security for 1 person in Ukraine & UAH & 2886,1 & 3337,6 & $115,6 \%$ \\
\hline Proceeds to the budget in Odessa & $\begin{array}{c}\text { UAH } \\
\text { thsd }\end{array}$ & 5395548,8 & 5613378,6 & $104,0 \%$ \\
\hline $\begin{array}{l}\text { Expenses by codes of economic } \\
\text { classification }\end{array}$ & $\begin{array}{c}\text { UAH } \\
\text { thsd }\end{array}$ & 5034574,7 & 5333777,7 & $105,9 \%$ \\
\hline
\end{tabular}

Source: compiled by the authors on the material [3]

4. Sensitivity of the city budget and economy to negative factors. Active actions of the regional authorities to modernize infrastructure, transport and housing and communal services require additional financing, which, among other things, takes place at the expense of paid resources, which leads to an increase in the debt burden on the regional budget. As of January 01, 2019, the consolidated debt burden indicator was $32,4 \%$, which corresponds to a moderate level of the debt burden. It is expected to fluctuate between 40-42\% in the future. Taking into account the longterm nature of most loans and convenient interest payment schedule, their servicing will not exert significant pressure on the budget revenues, at least under existing revenues. Thus, the impact of negative factors on the economy and financial solvency of the region remains moderate - the region's econo- mic complex is well diversified and has sufficiently adapted to the risks arising from the military conflict in eastern Ukraine and the introduction of trade restrictions between Ukraine and Russia.

Currently, 31 investment projects are being implemented in the Odessa Oblast in construction, industrial, trade and energy sectors. Among the companies to which the largest amount of foreign direct investment is directed, one can single out: «Delta Wilmar CIS» (food industry), «Odessa Port Production and Transhipment Complex», «Ukratlantik» (industrial equipment), «Company Ukrmill» (storage and processing of grain), «Euroterminal», «Cement» and «Beten International \& Valorem», Grossdorf liquid fertilizer plant, Grand Empire Building reinforced concrete structures plant, two solar and one wind power plant, preparation for the launch of Orlovka-Isakcha ferry 
crossing. It is planned to attract capital investments within the frame-work of public-private partnership for 25 years in three ports of Odessa region - Odessa, Chornomorsk and Yuzhnyi, which should amount to 70 billion UAH. It is also planned to implement a number of investment projects, including the construction of a grain handling complex together with the company «Brooklyn-Kyiv», implementation of projects of the companies «GPC-Ukraine», «Olimpex Coupe», etc. This is a joint project of one of the world's largest agricultural corporations Cargill (USA) and M.V. Cargo Company. The total value of the project amounted to $\$ 150$ million, including EBRD and IFC investments in the form of loans worth $\$ 74$ million [4].

The Odessa Regional Council is constantly taking measures to improve the investment climate, improve the quality of the region's management and provide administrative services. To this end, such activities were initiated and financially supported by local authorities in 2019:

1. Fourth International Business Forum «IV investment promotion forum Odessa 22-5T» (03-04.10.2018). The forum brought together about 600 participants and guests from 24 countries.

2. Business forum «Odessa $5 \mathrm{~T}$ Summer Business Day» (16.07.2019), in which 110 people took part. The participants had an opportunity to conduct allUkrainian net-working of film commissions, as well as production and production studios, discussed the role of cinema for tourism and marketing of cities.

3. Business forum «Marketing strategy «Odessa $5 T$ » - new face of the city» (27.05.2019). The event was attended by leading experts in marketing and tourism. Forum participants discussed topical issues of establishing a strategic marketing policy of the region, the de-velopment of urban marketing as a tool for growth of tourism potential and investment attraction.

4. In order to present the city investment potential, working meetings and foreign visits of the participants are organized [3].

The investment potential of the Odessa region is connected with such types of business: logistics and transport, agricultural sector, tourism, catering, hotels. The region is also promising to host assembly plants, including export of finished products to EU countries [5].

Conclusions. The article analyzes the main socio-economic indicators of development of the Odessa region, presents the dynamics of capital investment, the dynamics of foreign direct investment. The geographical structure of regional volume of foreign investments is considered; the level of investment activity is estimated.

Taking into account the above mentioned, we can state that for further attraction of investments into Odessa region it is necessary:

- facilitate preparation for implementation of pilot investment projects based on public and private partnership and introduce experience in implementation of pilot investment projects in different regions of the Odessa Oblast;

- improve the financial solvency of the region's population;

- remove barriers to foreign investment attraction; 
- create and implement a mechanism for sharing experience in investment attraction with other regions of Ukraine and countries around the world;

- conduct master classes, trainings for the participants of investment projects in order to activate their activities; actively use the Internet resource and social networks to display information directly related to attracting investments; attract mass media representatives to the development of investment activities [6]. Attracting investments to the region is a strategic direction of social and economic development of the region and Ukraine as a whole.

\section{REFERENCES}

1. Bondarchuk, $V$. Odesskiy region nuzhdaetsya $v$ investitsiyah. Retrieved from http://www.glasweb.com/ index.php/default/69906/odessa.[in Russian].

2. Odessa becomes more attractive for investment. Retrieved from https://odessalife.od.ua/news/odessa-stanovitsja-bolee-privlekatelnoj-dlja-investicij.

3. Report ODES 01-15 on updating the credit rating and investment attractiveness rating for 2019. Retrieved from http://ibi.com.ual UK/ company/odesa.html?type $==$ ar $\& I D=13$ [in Ukraine].

4. Pharmacy, S. \& Zhamoida, O. (2009). Rozvy'tok konkurenciyi v Ukrayini [Development of competition in Ukraine]. Economist of Ukraine. № 7, 13-21 [in Russian].

5. Kats, I.V. Odesskuyu oblast opyat poshli [In Odessa region again there were investments]. Odessa daily. Retrieved from http://odessa-daily.com.ua/lentaodnovostey/22164-investicii-v-oblast.html [in Russian].

6. Insty'tuciyi pidtry'mky' pidpry'yemny'cztva: koncepciya, osobly'vosti, diyal'nist' [The Institute of Education and Business: Concepts, Special Features, and Social] (2016). Center for Expertise, Representative Office to the Friedrich Naumann Foundation in Ukraine, USAID Program «Leadership in Economic Debt», 176 p. Retrieved from https://platforma-msb.org/wpcontent/uploads/2016/06/Catalogue-2016_web3.pdf [in Ukraine].

7. Fan, L. \& Luo, M. (2013). Analyzing ship investment behaviour in liner shipping. Maritime Policy \& Management, 40 (6), 511-533. Retrieved from: https://www.tandfonline.com/doi/abs/10.1080/03088839.2013.776183

8. Maslii, N., Zakharchenko, N., Butenko, V., Butenko, T. \&Shyriaieva, L. (2018). Modern technologies of detection and prevention of corruption in emerging information society. Problems and Perspectives in Management. Retrieved from https://businessperspectives.org/images/pdf/ applications/ publishing/templates/article/assets/9962/PPM_2018_01_Maslii.pdf

9. Lukasevich, I.Ya. Analiz dohodnosti kapitalnyih vlozheniy $v$ usloviyah byudzhetnyih ogranicheniy [Analysis of profitability of capital investments under budget constraints]. Finance, No. 3, 65-68 (1993) [in Russian].

10. Revenko, V.L. \& Lapkina I.A. (1997). Methods and models of investment analysis in the shipping industry. Cybern Syst Anal 33, 571-580. Retrieved from https://doi.org/10.1007/BF02733114 [in English]. 
11. Yedynyi derzhavnyi reiestr yurydychnykh osib, fizychnykh osib - pidpryiemtsiv ta hromadskykh formuvan. [перевод на английский]. Retrieved from https://usr.minjust.gov.ua [in Ukraine].

12. Oneshko, S. \& Ilchenko, S. (2017). Financial monitoring of the port industry companies on the basis of risk-oriented approach. Investment management and financial innovations. Vol. 14, №1(contin.), 191-199. Retrieved from http:// nbuv.gov.ua/UJRN/imfi_2017_14_1\%28contin.\%29_7

13. Savushkina, O.V. (2013). Metodicheskie aspekty anāiza investitsionnoy privlekatel'nosti sfer ekonomiki regiona. [Methodical aspects of the investment appeal analysis of the region spheres of economy]. Sotsial'no-ekonomicheskie yavleniya $i$ protsessy Socio-Economic Processes and Phenomena, 2013, no. 1(047), pp. 160-163 [in Russian].

14. Direct foreign investment (equity capital) from the country in Ukraine [2015]. State Statistics Service of Ukraine. Retrieved from https://goo.gl/qXSQo5.[in Russian].

15. Pogrishchuk, B. \& Kozlovsky, B. (2007). Methodology of investment and investment processes in Ukraine: camp and straightforward development [перевод на английский]. Nauka moloda-Science is young. No. 7, 125-130 [in Ukraine].

\section{СПИСОК ЛІТЕРАТУРИ}

1. Бондарчук В. Одесский регион нуждается в инвестициях. URL: http:// www.glasweb.com/ index.php/default/69906/odessa.

2. Одесса становится более привлекательной для инвестиций // Одесская жизнь. URL: https://odessa-life.od.ua/ news/odessa-stanovitsja-boleeprivlekatelnoj-dlja-investicij.

3. Отчет ODES 01-15 об обновлении кредитного рейтинга и рейтинга инвестииионной привлекательности за 2019 год. URL: http://ibi.com.ua/ UK/ company/odesa.html?type $=$ ar\&ID $=13$.

4. Аптекар С., Жамойда О. Розвиток конкуренщї в Україні // Економіка України. 2009. № 7. С. 13-21.

5. Каи И.В. Одесскую область опять пошли инвестиции // Odessa daily. URL:ttp://odessa-daily.com.ua/lenta-odnovostey/22164-investicii-v-oblast. html

6. Інституиії підтримки підприємництва: концепџія, особливості, діяльність. - Центр громадської експертизи, Представництво Фонду Фридріха Науманна в Україні, Програма USAID «Лідерство в економічному врядуванні», 2016. 176 c. URL: https://platforma-msb.org/wp-content/ uploads/2016/06/Catalogue-2016_web3.pdf

7. Фан Л., Луо М. Анализ инвестиционного поведения судов при линейных перевозках // Морская политика и управление. 2013. Bып. 40(6). C. 511-533. URL: https://www.tandfonline.com/doi/abs/ 10.1080/03088839. 2013.776183 
8. Маслий Н., Захарченко Н., Бутенко В., Бутенко Т., Ширяева Л. (2018). Современный технологии выявления и предотвращения коррупиии в формирующемся информачионном обществе // Проблемы и перспективы в управлении. URL: https://businessperspectives.org/images/pdf/applications/ publishing/templates/article/assets/9962/PPM_2018_01_Maslii.pdf.

9. Лукашевич И.Я. Анализ доходности капитальных вложений в условиях бюджетных ограничений // Финансы, № 3, 65-68 (1993).

10. Revenko V.L. \& Lapkina I.A. Methods and models of investment analysis in the shipping industry. Cybern Syst Anal 33, 571-580 (1997). [Электронный pecypc]. URL: https://doi.org/10.1007/BF02733114

11. Сдиний державний реєстр юридичних осіб, фізичних осіб-підприємиів та громадських формувань. URL: https://usr.minjust.gov.ua.

12. Oneshko S., Ilchenko S. Financial monitoring of the port industry companies on the basis of risk-oriented approach // Investment management and financial innovations. 2017. Vol. 14, № 1 (contin.). C. 191-199. URL: http://nbuv. gov.ua/ UJRN/imfi_2017_14_1\%28contin.\%29_7.

13. Савушкина О.В. Методические аспекты анализа инвестиционной привлекательности сфер экономики региона // Сочиально-экономические явления и прочессы. 2013. № 1(047). С. 160-163.

14. Прямі іноземні інвестииії (акиіонерний капітал) з країн СС в економіиі України [на 01.07.2015] // Державна служба статистики Украӥни. URL: https://goo.gl/qXSQo5.

15. Погрішук Б., Козловський В. Методологія дослідження інвестииійних прочесів в Украӥні: стан і напрямки розвитку // Наука молода. 2007. № 7. C. $125-130$.

Article received 30.06.2020

Reference a JournalArtic: Shiryaeva, Lyudmila \& Komarova, Yuliia. (2020). Analysis of investment attractiveness of Odessa region. Development of management and entrepreneurship methods on transport. 3 (72), 12-21. DOI 10.31375/2226-1915-2020-3$12-21$. 